\title{
Bioprospection of Yeasts as Biocontrol Agents Against Phytopathogenic Molds
}

\author{
Márcia Maria Rosa-Magri ${ }^{*}$, Sâmia Maria Tauk-Tornisielo ${ }^{2}$ and Sandra Regina Ceccato- \\ Antonini $^{1}$ \\ ${ }^{1}$ Centro de Ciências Agrárias; Universidade Federal de São Carlos; 13600-970; Araras - SP - Brasil. ${ }^{2}$ Centro de \\ Estudos Ambientais; Universidade Estadual Paulista; 13506-900; Rio Claro - SP - Brasil
}

\begin{abstract}
Yeasts isolated from sugar cane and maize rhizosphere, leaves and stalks were screened against the phytopathogenic molds Colletotrichum sublineolum and Colletotrichum graminicola, both causal agents of the anthracnose disease in sorghum and maize, respectively. Strains identified as Torulaspora globosa and Candida intermedia were able to inhibit the mold growth, with the first species also exhibiting killer activity. No previous report on the application and potentiality of these yeasts as biocontrol agents were found neither the killer phenotype in Torulaspora globosa.
\end{abstract}

Key words: bioprospection, Colletotrichum graminicola, Colletotrichum sublineolum, killer activity, mycocinogenic

\section{INTRODUCTION}

The control of phytopathogenic molds by yeasts has been studied with great potential usage, mainly inhibiting molds that cause fruit rotting in postharvesting period, because the yeast is a good competitor for nutrient and space (Druverfors et al., 2005; Coelho et al., 2007; Zhang et al., 2007). Positive results have been also found in literature for the biocontrol of plant diseases by yeasts in field situations (El-Tarabily, 2004).

The mechanisms of yeast action towards the molds are varied as the production of killer toxins (Walker et al., 1995); of hydrolytic enzymes capable to degrade the cell wall of phytopathogenic molds (Masih and Paul, 2002; Urquhart and Punja, 2002); and of toxic volatile compounds (Bruce et al., 2004).
Nevertheless, the yeast ability to develop quickly in leaf, fruit and flower surfaces, especially in sugar-rich habitats, dominating this environment and excluding the other microorganism growth by means of competition for space and nutrients, seems to be the most common way of biocontrol (Valdebenito-Sanhueza, 2000).

The challenge is the understanding of how the yeast behaves in agricultural areas, discovering how this microorganism group can help in the production process, contributing for the ecosystem equilibrium with the decrease in the fungicide usage.

Anthracnose in Brazil is considered an important disease in sorghum and maize, occurring widely wherever these cultures are produced (Pinto, 2003). The frequent precipitation seems to be the

*Author for correspondence: marcia@cca.ufscar.br 
common factor in areas where this disease occurs. Reduction in $50 \%$ of grain production or even higher, in severe epidemies (Warren, 1986) as well as diminished grain or seed quality (Casela et al., 1992) has been reported.

The most effective method of control is the usage of genetically resistant varieties, however, this is difficult due to the high variability presented by the mold, which in turn determines the fast adaptation of the pathogen to the resistant cultivar (Casela and Ferreira, 1991).

High specificity between phytopathogen and host are observed for $C$. graminicola isolates from maize and sorghum, indicating they are distinct from each other and considered as formae speciales or distinct species (Costa et al., 2003). In this respect, the modification of the species name to C. sublineolum P. Henn., Kabat and Bubak was proposed for the pathogenic mold in sorghum culture.

A potential alternative for the control of anthracnose disease in field is here presented by means of antagonistic action of yeasts isolated from agricultural areas. The purpose of this study was the isolation and evaluation of yeasts from sugar cane and maize cultures for the biocontrol of two phytopathogenic molds, causing anthracnose in sorghum and maize.

\section{MATERIALS AND METHODS}

Yeasts were isolated from rhizosphere soil, leaves and stalks from sugar cane and maize. The sampling was carried out in sugarcane twice: at the start of the development (50-cm high) in March 2007, and at the end of the development (right before the harvest), in September 2007. For the maize, the samples were taken once, at the phonological state R1 (flowering and polinization) in March 2008.

The rhizosphere soil was collected from $0-20 \mathrm{~cm}$ of depth from the sugar cane and maize plants. The stalks and leaves were cut aseptically and shaken for 30 minutes at $250 \mathrm{rpm}$ in saline solution.

The isolation procedures follow Azeredo et al. (1998), using serial dilution of the samples in saline solution $(\mathrm{NaCl} 0.85 \%)$ and plating in three culture media (YEPD $-1 \%$ yeast extract, 2\% peptone, $2 \%$ glucose, $2 \%$ agar, $0.01 \%$ ampicilin, $0.01 \%$ nalidixic acid; YM $-0.3 \%$ yeast extract, $0.3 \%$ malt extract, $0.5 \%$ peptone, $1 \%$ glucose, $2 \%$ agar, $0.01 \%$ ampicilin, $0.01 \%$ nalidixic acid; and WL Nutrient Agar, Acumedia ${ }^{\circledR}$, added with $0.01 \%$ ampicilin, $0.01 \%$ nalidixic acid). The plates were incubated at $25^{\circ} \mathrm{C}$ for 3-7 days and yeast colonies were screened for colony and cell characteristics, isolated and purified in YEPD medium. The colonies were maintained in agar slants at $4^{\circ} \mathrm{C}$.

Following the strains were screened in vitro for antagonistic behavior against Colletotrichum sublineolum and Colletotrichum graminicola molds, kindly provided by Embrapa Milho e Sorgo, in Potato Dextrose Agar Medium, pH 5.0, incubating at $25^{\circ} \mathrm{C}$ for 10 days.

The yeast isolates inhibiting mold growth were identified by the sequencing of the ITS region in ribosomal DNA (White et al., 1994). The fingerprinting technique used was ISSR (Inter Simple Sequence Repeats) with the primer $\mathrm{GTG}_{5}$, according to Silva-Filho et al. (2005).

Killer activity was also assessed in the isolates, according to Ceccato-Antonini et al. (2004), using buffered YEPD-methylene blue at $\mathrm{pH}$ 4.5-4.7. Aliquots of $100 \mu \mathrm{L}$ of the sensitive strains Saccharomyces cerevisiae NCYC 1006 and Torulopsis glabrata ATCC 15126 at cell suspensions of $4 \times 10^{5}$ cells $/ \mathrm{mL}$ were spread on the culture medium. The test strains were inoculated with sterile toothpicks following incubation at $30^{\circ} \mathrm{C}$ for 3 days. The isolates were considered mycocinogenic (killer toxin producers) when an inhibition halo and blue zone were produced around the isolate, indicating cell death of the sensitive strain.

\section{RESULTS AND DISCUSSION}

A total of 317 yeast colonies were isolated, the majority from the leaf surface, followed by stalk and rhizosphere soil (Figure 1). Indeed, the yeast population in soil is lower comparing to bacteria and molds (El-Tarabily and Sivasithamparam, 2006). The leaf surface and fruits are more adequate for the fast yeast growth due to the higher sugar content (Sharma et al., 2009). 


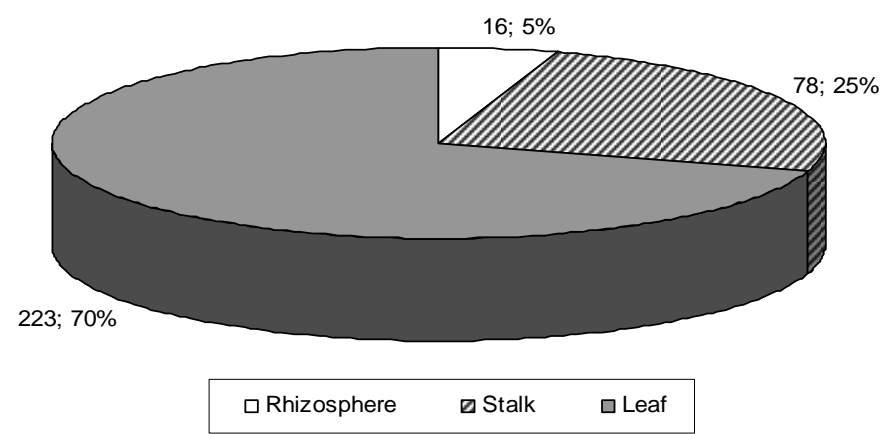

Figure 1 - Number and percentage of yeasts isolated from the rhizosphere, stalk and leaf of sugar cane and maize.

The antagonism tests with all the yeasts isolated against $C$. graminicola and $C$. sublineolum have shown only eight isolates $(2.5 \%)$ able to inhibit the mold growth, with six belonging to the species Torulaspora globosa and two identified as
Candida intermedia (Table 1). These yeasts presented an inhibition halo towards the molds that remained for all the incubation period, as demonstrated in Figure 2.

Table 1 - Yeast strains source, identification, killer activity and antagonism percentage against Colletotrichum graminicola (CG) and Colletotrichum sublineolum (CS).

\begin{tabular}{clcccc}
\hline Yeast strain & Source* & Identification & Killer factor & Antagonism (\%) & CG \\
\hline 1S110 & Rhizosphere & T. globosa & present & 47.6 & 57.9 \\
1S111 & Rhizosphere & T. globosa & present & 45.9 & 58.3 \\
1S112 & Rhizosphere & T. globosa & present & 52.7 & 60.3 \\
2S01 & Rhizosphere & T. globosa & present & 50.0 & 57.5 \\
2S02 & Rhizosphere & C. intermedia & absent & 48.9 & 47.7 \\
2S03 & Rhizosphere & C. intermedia & absent & 45.9 & 48.9 \\
2S04 & Rhizosphere & T. globosa & present & 49.8 & 55.9 \\
2F58 & Leaf & T. globosa & present & 48.7 & 58.3 \\
\hline
\end{tabular}

* All of the yeast strains were isolated from sugar cane.

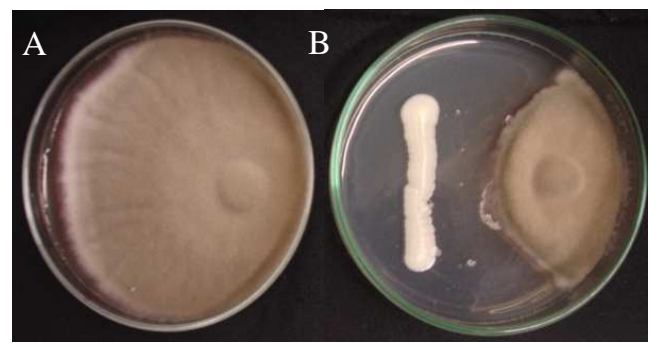

Figure 2 - Antagonism by the yeast $T$. globosa against the phytopathogenic mold C. graminicola in PDA medium. A- only mold; B- yeast (left) against mold (right).

All the isolates were obtained from sugar cane, especially from rhizosphere. Although the leaf is the main source of yeasts, the soil is the habitat of the antagonists. The fact that the soil is a complex environment with a high microbial diversity may imply that only the microorganisms that show antagonistic mechanisms of defense and competition are able to adapt and survive in this ecosystem.

The low number of antagonists isolated from the environment is not a surprise, since many other works have found similar results 
(Chanchaichaovivat et al., 2007; Cabral et al., 2009; Wang et al., 2009).

Another point to be considered was the result of isolation of six yeasts of the same species ( $T$. globosa) from different sources and sampling times in the same plant (rhizosphere soil and leaf). The possibility of belonging to the same strain led to the application of a fingerprinting technique based in ISSR (Inter simple sequence repeats) with the primer $\mathrm{GTG}_{5}$. All the six isolates have shown the same genetic profile (DNA bands), which is an indication of that yeast is widespread in the environment. No previous report on the application and potentiality of these yeasts as biocontrol agents was found and so, the mechanisms of action are unknown.

Killer toxins may be responsible for the biocontrol of pathogenic molds and Walker et al. (1995) were the first authors to report it. Others as Santos et al. (2004) and Coelho et al. (2007) have also found positive results for killer yeasts inhibiting phytopathogenic molds. Here the killer assays revealed that $T$. globosa is a toxin-producing yeast (Table 1). As far as we know, this is the first report on the killer toxin production by this yeast species. Of course other mechanisms of action must be surveyed but these preliminary results are promising.

The results are encouraging by considering that this yeast was isolated from the rhizosphere and leaf surface, naturally found in agricultural areas. Further studies are in course to evaluate in vivo effects of the yeast application in the biological control of the causal agent of anthracnose in sorghum. The mechanisms of action have been also studied in order to identify the means by which the yeast controls the mold growth.

\section{ACKNOWLEDGMENTS}

The authors wish to thank $\mathrm{CNPq}$ for the grant to the first author.

\section{REFERENCES}

Azeredo, L.A.I.; Gomes, E.A.T.; Mendonça-Hagler, L.C. and Hagler, A.N. (1998), Communities associated with sugarcane in Campos, Rio de Janeiro, Brazil. Int. Microbiol., 1:205-208.
Bruce, A.; Verrall, S.; Hackett, C.A. and Wheatley, R.E. (2004), Identification of volatile organic compounds (VOCs) from bacteria and yeast causing growth inhibition of sapstain fungi. Holzforschung, 58: 193-198.

Cabral, A.S.; Carvalho, P.M.B.; Pinotti, T.; Hagler, A.N.; Mendonça-Hagler, L.C.S. and Macrae, A. (2009), Yeast inhibit the growth of the phytopathogen Moniliophthora perniciosa, the causal agent of 'witches' broom disease. Braz. J. Microbiol., 40: 108110.

Casela, C.R. and Ferreira, A.S. (1991), Resistência parcial a diferentes raças de Colletotrichum graminicola. Relatório Técnico Anual do Centro Nacional de Pesquisa de Milho e Sorgo 1988-1991, Sete Lagoas, 4: 130 - 131.

Casela, C.R.; Ferreira, A.S. and Schaffert, R.E. (1992), Sorghum diseases in Brasil. In: Miliano, W.A.J.de; Frederiksen, R.A.; Bengston, G.D. (Ed.). Sorghum and millets diseases: a second world review. Patancheru. ICRISAT, p.57-62.

Ceccato-Antonini, S. R.; Tosta, C. D. and Silva, A. C. (2004), Determination of yeast killer activity in fermenting sugarcane juice using selected ethanolmaking strains. Braz. Arch. Biol. Technol., 47: 1323.

Chanchaichaovivat, A.; Ruenwongsa, P. and Bhinyo, P. (2007), Screening and identification of yeast strains from fruits and vegetables: Potential for biological control of postharvest chilli anthracnose (Colletotrichum capsici). Biol. Control, 47:326-335.

Coelho, A.R.; Celli, M.G.; Ono, E.Y.S.; Wosiacki, G.; Hofmann, F.L.; Pagnocca, F.C. and Hirooka, E.Y. (2007), Penicillium expansum versus antagonist yeasts and patulin degradation in vitro. Braz. Arch. Biol. Technol., 50(4), 725-733.

Costa, R.V.; Casela, C.R.; Zambolim, L. and Ferreira, A.S. (2003), A antracnose do sorgo. Fitopatol. bras., 28 (4): 345-354.

Druverfors, U.A.; Passoth, V. and Schnurer, J. (2005), Nutrient effects on biocontrol of Penicillium roqueforti by Pichia anomala J121 during airtight storage of wheat. Appl. Environ. Microb., 71(4): 1865-1869.

El-Tarabily, K.A. (2004), Suppression of Rhizoctonia solani diseases of sugar beet by antagonistic and plant growth-promoting yeast. J. Appl. Microb., 96: 69-75.

El-Tarabily, K.A. and Sivasithamparam, K. (2006), Potential of yeasts as biocontrol agents of soil-borne fungal plant pathogens and as plant growth promoters. Biom. Life Sci., 47(1):25-35.

Masih, E. I. and Paul, B. (2002), Secretion of beta-1,3glucanase by the yeast Pichia membranifaciens and its possible role in the biocontrol of Botrytis cinerea causing mold disease of the grapevine. Curr. Microbiol., 44: 391-395. 
Pinto, N.F.J.A. (2003), Controle químico da antracnose (Colletotrichum graminicola) do sorgo. Revista Brasileira de Milho e Sorgo, 2(3), p.148-152.

Santos, A.; Sanchez, A. and Marquina, D. Yeasts as biological agents to control Botrytis cinerea. Microbiol. Res., 159:331-338.

Sharma, R.R.; Singh, D. and Singh, R. (2009), Biological control of postharvest diseases of fruits and vegetables by microbial antagonists: A review. Biol. Control, 50: 205-221.

Silva-Filho, E.A.; Santos, S.K.B.; Resende, A.M.; Morais, J.O.F.; Morais Junior, M.A. and Simões, D.A. (2005), Yeast population dynamics of industrial fuel-ethanol fermentation process assessed by PCRfingerprinting. Antonie van Leeuwenhoek, 88:13-23.

Urquhart, E. J.; Punja, Z. K. (2002), Hydrolytic enzymes and antifungal compounds produced by Tilletiopsis species, phyllosphere yeasts that are antagonists of powdery mildew fungi. Can. J. Microbiol., 48: 219-229.

Valdebenito-Sanhueza, R.M.V. (2000), Leveduras para o controle de fitopatógenos. In: Melo, I.S. and Azevedo, J.L. Controle biológico. 1st Ed., v.2, Embrapa Meio Ambiente, Jaguariúna, p.41-56.

Walker, G.M.; McLeod, A. H. and Hodgson, V. J. (1995), Interactions between killer yeasts and pathogenic fungi. FEMS Microb. Lett., 127: 213-222.
Wang, X.; Li, G.; Jiang, D. and Huang, H.C. (2009), Screening of plant epiphytic yeasts for biocontrol of bacterial fruit blotch (Acidovorax avenae subsp. citrulli) of hami melon. Biol. Control, 50:2, 164-171.

Warren, H.P. (1986), Leaf anthracnose. In: Frederiksen, R.A. (Ed.). Compendium of sorghum diseases. St. Paul: American Phytopathological Society, p.10 - 11.

White, T.J.; Bruns, T.; Lee, S. and Taylor, J. (1994), Amplification and direct sequencing of fungal ribosomal RNA genes for phylogenetics. In: Innis, M.; Gelfand; D.H.; Sninsky, J.J. and White, T.J. (Ed.). PCR protocols: a guide to methods and applications. Academic Press, New York, p.315-321.

Zhang, H.Y.; Wang, L.; Dong, Y.; Jiang, S.; Cao, J. and Meng, R.J. (2007), Postharvest biological control of gray mold decay of strawberry with Rhodotorula glutinis. Biol. Control, 40: 287-292.

Received: September 10, 2009; Revised: April 28, 2010; Accepted: October 07, 2010. 